\section{Las ensoñaciones de un videasta solitario}

Richard Skryzak*

Resumen: Para un estudiante en arte como yo, inmerso en la práctica de la pintura a comienzos de los años 80 , la utopía original del videoarte consistía principalmente en la aparición de una nueva forma de expresión artística, percibida tanto como un respiro y una salida que permitiese refrescar mi práctica y salir del callejón sin salida de la estética vanguardista inmersa entonces en la controversia entre pintura neo-expresionista y arte conceptual-minimalista.

Por lo cual yo seguiría pintando, pero con video. Desde entonces dos problemas de fondo continúan alimentando mi reflexión y mi trabajo. ¿Podemos ver el video en pintura? ¿Podemos ver la pintura en video? La originalidad de mi trabajo videográfico reside en tener sus raíces estéticas e históricas en la historia del arte, llevado de manera simultánea con una investigación a fondo de las cualidades del medio electrónico, a la luz de los conceptos de "Vanidad" y "Cuadro-Video".

Tomo como referencia al filósofo Jean-Jacques Rousseau quien frente al aburrimiento de los salones, equivalente a nuestros "vernissages“, concibió su "moral del balero". Casualmente, realicé hace unos años un video que muestra un balero en acción.

Un día filmaré mis ensoñaciones de un videasta solitario.

Palabras clave: J. J. Rousseau - pintura - vanidad - video.

[Resúmenes en inglés, portugués, francés y sueco en las páginas 166-167]

${ }^{(*)}$ Estudió Arte y Literatura. Se desempeña como profesor de video y análisis de la imagen desde 1988.

"No basta con tener talento: es necesario además contar con vuestra autorización, ¿no es así, amigos míos?” (Nietzsche, 1971)

Esto es lo que podía escuchar un estudiante como yo, en una escuela de arte dedicada a la práctica de la pintura, hacia comienzos de los años 80 . 
La pintura ha muerto mi viejo, la escultura también, el arte es la muerte. ¿Qué quieren? ¿Pintura? No la conozco. ¿Emoción? ¿Y qué más? ¿Deseo? ¿Qué es eso? ¿Lo sensible? ¡No estamos aquí para eso! ¿Placer? ¡Ya están sobrepasando los límites!! Todo eso está terminado, prohibido, desechado. Hoy estamos con el concepto, siempre el concepto, y nada más que concepto; $y$ un poco de minimalismo, si se portan bien! (Tal era la palabra dominante, heredera de los escritos y posiciones teóricas de artistas como Kosuth, Art and Language, Weiner o Buren, de comienzos de los años 70)

Armado con mis pinceles y mi deseo de ser artista, descubro la dimensión castradora del discurso teórico sobre el arte contemporáneo que nos hostigaba entonces, y que aun hoy sigue alimentando la versión oficial. Un dilema se me presenta entonces, ¿̇hacia dónde ir? Por un lado una pintura perdida entre post-hiperrealismo, neo-abstracción y figuración narrativa. Por el otro, la frialdad desencarnada y arrogante del arte minimal, o la pretensión seudo-filosófica del arte conceptual. $\mathrm{O}$ aun una tercera vía que mezcla los géneros revistiendo el todo de coartadas teóricas tomadas de prestado, grosso modo, de las ciencias humanas o, simplemente, de las ciencias.

¿Qué hacer con eso? ¿Cómo salir de este maldito impasse? ¿Cómo encontrar el inédito modo de expresión que conserve intacta mi voluntad de hacer arte?

En primer lugar, el cine paralelo, de vanguardia, underground, experimental, como se quiera. Una primera apertura. Eggeling, Ruttmann, y el regreso a los orígenes, el dibujo animado al pie de la letra. Luego, Léger, Warhol, Nekes, Kubelka. Sí, eso también es cine. Sin medios, sin historia, sin fin. Un plano fijo y listo. Es posible y existe...

Primeras pruebas con una Super 8 Beaulieu comprada de segunda mano en Bélgica.

Y entonces aparece el videoarte...

Primeras obras de Paik, Vostell, Viola.

Recuerdo en particular TV as a fire place de Ian Dibbets en el museo de Gante. Una obra potente por su simplicidad y radicalidad. El televisor muestra unos troncos ardiendo. La televisión ha reemplazado a la chimenea en los hogares. Tenemos todo el tiempo para encontrarnos, observar y meditar. El agua y el fuego serán dos constantes del videoarte. Bachelard es de pronto el primer teórico. No se puede ser más claro. Este lenguaje se dirige a mí. Y entonces todo se aclara. Es como descubrir un nuevo territorio.

Obviamente es hacia allí que hay que ir. La televisión no se encuentra lejos. Ella me crió como espectador. Por mi parte yo criaré mi propia televisión. Eso es el vídeo arte para aquéllos que realmente comprendieron lo que pasó. Para todos aquéllos que vivieron los orígenes de la televisión (la de Averty, Dumayet, Barma, Santelli...). Para todos aquéllos que comprendieron que la televisión, antes de ser despreciada como agente formador de ideología de masas o máquina productora de estupidez, nos ha sobre todo construido como sujetos cultivados, inteligentes y sensibles a las pantallas. Digámoslo de una buena vez. ¡La TV ha formado más creadores y artistas que todas las escuelas de arte reunidas! Nuevo medio. Nuevos aires. Verdadera respiración para refrescar mi práctica. Se tratará por lo tanto de continuar a pintar, pero con el vídeo. No hay problema, ya que en el campo del arte, un medio siempre ha ocultado a otro medio. ¿Un ejemplo? Aquéllos que todavía creen que Lascaux es sólo el nacimiento de la pintura deben mirarla un poco más de cerca. 
Ella nos habla de movimiento, de sobreimpresión, de fundido, de luz, de proyección, de embrujo. Lascaux es un espectáculo audio-visual avant la lettre, y el mismo alrededor de un fuego, si es que ven lo que estoy queriendo decir.

Desde entonces dos cuestiones de fondo no cesarán de alimentar mi reflexión y mi trabajo. ¿Podemos ver el vídeo en pintura? ¿Podemos ver la pintura en video?

Comencé por realizar Electrón; ya que de empezar se trata empecemos por el origen, un cruce entre Klee y Fischinger. Un precipitado de mis investigaciones semióticas y un estribillo poético. Definir el grado Uno de la imagen y llegar a la Luna.

Y a partir de allí todo se va encadenando.

¿Qué es lo que nos permite conectar al cine con la televisión? El Video. ¿ Qué es lo que nos permite reactivar la pintura? El Video. ¿ Qué es lo que nos permite escribir con otra cosa que no sean palabras? El Video.

Constato que los principales problemas estéticos y filosóficos que me preocupan, el Casi Nada, la Vanidad, la Levedad, lo Efímero, concuerdan perfectamente con la imagen electrónica. Se podría incluso decir que el video fue creado por ellos. Luego, para mí.

A fuerza de buscar, se ha encontrado una prueba.

La Vanidad es el Tiempo. El Vídeo es el Tiempo. De modo que La Vanidad es Vídeo. In Video Vanitas. Tan simple como eso.

Voy a desarrollar todos estos temas de obra en obra y como recompensa un regalo del cielo. Un arco iris. ¡A cada cual su propia iluminación!

En aquella época pocos videastas encaraban el vídeo bajo este ángulo, y aun hoy la dimensión poética de mis producciones contrasta con el egocentrismo generalizado. La originalidad de mi obra videográfica ha residido siempre en este anclaje estético e histórico con la historia del arte, llevada a cabo junto a una investigación exhaustiva de las cualidades del médium electrónico, especialmente gracias a la ayuda de los conceptos de Vanidad y de Videos-Cuadros. Es así que nacieron obras como Electron, Ecran, In Video Vanitas, Les Attributs du Vidéaste, L'arc-en-ciel, Vanité à la Tulipe, Autoportrait à la bulle.

Eso es. Para mí, la utopía original del video es esencialmente la siguiente: haberme permitido salir del bloqueo estético de la modernidad y de su ideología milenarista (que sólo un Jean Clair ha tenido el coraje y la inteligencia de señalar desde 1983 en su libro Considérations sur l'état des beaux-arts).

Algo más. Asociado alguna vez al arte sociológico de Fred Forest, por su impacto directo con el público, prometía además eliminar las rígidas y elitistas barreras del arte, logrando así la dimensión colectiva tan esperada.

Le debo todo al video: el reconocimiento artístico, el motor de mis ensayos teóricos, mi actividad como docente en la escuela de arte y la universidad, mis mejores encuentros poéticos y afinidades eléctricas (Don Foresta, Alain Bourges, Danielle et Jacques-Louis Nyst, Jean-Paul Tréfois, Marc Mercier, Jean-Paul Fargier...). Le debo haber podido poner imágenes detrás de la palabra Deseo. Y le debo haber podido poner palabras detrás de esas imágenes. Darles sentido. Gracias a ella poco a poco me di cuenta de que la imagen siempre ha estado del lado de la magia. No sólo porque es su anagrama (nota del traductor: en francés image / magie), sino porque ontológicamente participa de un poder de alucinación, de un trastorno de la percepción, que es el origen de mi deseo de crear. De situarme en el corazón de una Visión, de una Revelación. De hacer Visible lo que hasta entonces era 
In-Visible o Impre-Visible. Es por eso que en latín vídeo significa yo veo. Es imparable. Llegó para enseñarnos a ver. "Tenemos ojos pero no vemos", dice la Biblia (Jeremías 5). ¿Qué vemos de un pétalo de tulipán que cae, de una burbuja que estalla, de un arco iris, de un relámpago? Es para responder a esta pregunta que hago videos. Para que ellos me construyan tanto como yo los construyo. Todo esto me lo ha enseñado el vídeo.

Hice mi primera exposición colectiva de videoarte en 1986, a la edad de 26 años, junto a Vostell, Nam June Paik, Klaus Vom Bruch y Thierry Kuntzel. ¡Qué tal! Como bautismo de fuego, difícilmente pueda hacerse algo mejor.

Es la primera vez que me cruzaba con Thierry Kuntzel. Conocía sus escritos sobre la teoría del cine. Estaba impresionado porque él había seguido el seminario de Roland Barthes, algo que le envidiaba porque yo pongo por encima de todo a Barthes. Intercambiamos unas pocas palabras. Soy tímido. El muestra La Desserte Blanche en una habitación completamente pintada de blanco. Depurada. Y me doy cuenta de que exploramos los dos, cada uno a su manera, los límites de la imagen vídeo. Yo presento un dispositivo con el nombre de 'Ecran'. Está constituido por un proyector de cine súper 8 que proyecta en bucle, sobre la pantalla de un televisor apagado, la señal de ajuste, la imagen de las barras de color filmada con anterioridad. Se trataba entonces de saber si podíamos hacer video sin imagen electrónica, utilizando la imagen símbolo de televisión, las barras color, a través del médium cinematográfico. ¿Cuál era el estatus de esta imagen? ¿Cómo definir una imagen que no es realmente ni cine ni televisión, y que sin embargo aun no es video? ¿O que es las tres a la vez? Anti-vídeo. Contra-vídeo. Nivel cero. Este es el tipo de preguntas que me hago. Y que más tarde, un Raymond Bellour teorizará a través del concepto de 'Entre-Imagen'.

Siempre he estado fascinado por la idea de que una imagen pudiese viajar, ser nómada, cambiar de soporte, de sustancia, pasar de la pintura a la fotografía o al vídeo y que esa transferencia se convirtiese en campo de verdaderos fenómenos de 'des-territorialización' y de 're-territorialización' estéticos y semánticos. Yo creo en la 'Reencarnación' de las imágenes.

Volví a encontrarme con Küntzel años más tarde cuando, ya siendo artista-profesor en la Escuela de Arte de Dunkerke, lo invité a presentar las dos instalaciones Eté et Hiver a lo cual él accedió amablemente. Se había convertido en el videasta francés más famoso. Se acordaba de mí. Pasamos noches inolvidables conversando sobre el arte y la vida. ¡Y especialmente a reír! Lo que siempre me ha gustado en él es que pusiera en un mismo plano la semiología del cine y los discos simples de vinilo de los cantantes franceses de la década del 60.

Compartí recientemente, en 2009, dos manifestaciones importantes junto a Bill Viola. Una en el Centro Cultural Francés de Ramallah en Palestina y la otra en el Musée de l'Orangerie en París, donde di dos conferencias. Bello reconocimiento para mi atípica carrera. Ya que, como provinciano, siempre he tenido un problema en relación con la notoriedad. Mis modestos orígenes sociales (hijo de un minero del norte de Francia) me invitan a la humildad y a la integridad; valores poco eficaces para el reconocimiento oficial 
e institucional. Francia sigue siendo un país profundamente jacobino. Cultural y artísticamente, es un territorio ocupado. Los parisinos hablan a los parisinos. La provincia escucha, padece o imita. Sin embargo, aun estando al margen, esto no ha impedido que mis cualidades sean valoradas, mis competencias reconocidas y mis obras difundidas en lugares prestigiosos (Rotterdam, el Musée de l'Orangerie, Palestina, el canal "Arte" de televisión....). Como escribiera Jean-Yves Jouannais en 1997 "Por un lado están los artistas y por el otro, aquéllos que agotan su tiempo tratando de dar pruebas de que son artistas". Yo formo parte de la primera categoría. Pero hay un precio a pagar.

Traigo a modo de referencia a Jean-Jacques Rousseau. El filósofo de la ruptura, la utopía y la amistad... Al igual que él, yo odio la vida mundana, la hipocresía y la impostura, los cagones mentirosos (¡y los cagones que se mienten a sí mismos!). ¡Desde este punto de vista el mundo del arte se encuentra muy bien servido! Ante el aburrimiento de los salones, equivalentes a nuestros vernissages, Rousseau elabora su 'moral del balero', que describe en estos términos en sus Confesiones (2011):

Si volviese al mundo, llevaría siempre un balero en mi bolsillo y jugaría todo el día para evitar hablar cuando no tenga nada que decir. Si todos hicieran lo mismo los hombres serían menos malvados, las relaciones serían más seguras y hasta más agradables. En fin, que los bromistas se rían si quieren, pero yo sostengo que la única moral al alcance de la época que nos toca vivir es la moral del balero (Rousseau, 2011).

¡No podríamos describir de mejor manera nuestra sociedad del espectáculo!

Con mucho gusto le respondo con una Estética del Balero, inaugurada hace algunos años por un vídeo que representa un balero en acción, y que continúo elaborando en oposición a la creación dominante, ya que la situación actual del arte contemporáneo no parece estar pronta a mejorar.

Un día, filmaré mis ensoñaciones de un videasta solitario.

\section{Referencias Bibliográficas}

Clair, J. (1983). Considérations sur l'état des beaux-arts. París: Gallimard.

Jouannais, J. Y. (1997). Artistes sans œuvres. París: Hazan.

La Bible. (1979). Traduction œcuménique. París: Le Livre de Poche.

Nietzsche, F. (1971). Par-delà le bien et le mal. París: Gallimard.

Rousseau, J. J. (2011). Les Confessions. París: Garnier. 
Summary: For an art student like me, immersed in the practice of painting in the early ' 80 s, the original utopia video art mainly consisted in the appearance of a new form of artistic expression, perceived both as a breath and an output that allowed to refresh my practice and leave the dead end of the aesthetic vanguard then immersed in the controversy between neo-expressionist painting and minimalist conceptual art. Therefore I continue painting, but with video. Since then two underlying problems continue to fuel my thinking and my work. Can we see the video as a painting? Can we see the video painted? The originality of my video work lies in having aesthetic and historical roots in the history of art, taken simultaneously with a thorough investigation of the qualities of the electronic media, in the light of the concepts of "Vanity" and "Painting-Video ". I take as a reference to the philosopher Jean-Jacques Rousseau who dealing with the boredom of the saloons, equivalent to our "opennings", conceived his "cup-and-ball moral ." Coincidentally, I made a video a few years ago showing a cup-and-ball in action. One day I'll film my dreams as a solo videographer.

Key words: J. J. Rousseau - painting - vanity - video.

Resumo: Para um estudante em arte como eu, imerso na prática da pintura a começos dos anos 80 , a utopia original do vídeo arte consistia principalmente na aparição de uma nova forma de expressão artística, percebida tanto como um respiro e uma saída que permitisse refrescar minha prática e sair de uma rua sem saída da estética vanguardista imersa então na controvérsia entre pintura neo-expressionista e arte conceitual minimalista.

Por isso, eu seguiria pintando, mas com vídeo. Desde esse momento, dois problemas de fundo continuam alimentando minha reflexão e meu trabalho. Podemos ver o vídeo em pintura? Podemos ver a pintura em vídeo? A originalidade do meu trabalho vídeográfico reside em ter suas raízes estéticas e históricas na história da arte, levado de modo simultâneo com uma pesquisa a fundo das qualidades do meio eletrônico, à luz dos conceitos de "vaidade" e "quadro-vídeo".

Faço referencia ao filósofo Jean-Jacques Rousseau quem frente ao tédio dos salões, equivalente a nossos vernissages, concebeu sua "moral de bilboquê". Casualmente, fiz há uns anos, um vídeo que apresenta um bilboquê em ação. Um dia filmarei meus sonhos de videasta solitário.

Palavras chave: J. J. Rousseau - pintura - vaidade - vídeo.

Résumé: Pour un étudiant en école d'art comme moi, engagé dans une pratique picturale, au début des années 80 , l'utopie originelle de l'art vidéo a avant tout consisté en l'apparition d'un nouveau mode d'expression artistique, perçu à la fois comme une respiration et une issue permettant de rafraîchir ma pratique et de sortir de l'impasse esthétique des avant-gardes, embourbée à l'époque dans la querelle peinture néo-expressionniste/art conceptuel-minimal.

Il s'agira donc pour moi de continuer à faire de la peinture, mais avec la vidéo. Dès lors deux questions de fond ne cesseront d'alimenter ma réflexion et mon travail. Peut-on 
voir la vidéo en peinture? Peut-on voir la peinture en vidéo ? L'originalité de mon œuvre vidéographique a toujours résidé dans cet ancrage esthétique et historique avec l'histoire de l'art, mené de pair avec une investigation en profondeur des qualités du medium électronique, sous l'éclairage notamment des concepts de Vanité et de Tableaux-Vidéos. Je me réfere volontiers au philosophe Jean-Jacques Rousseau. Face à l'ennui des salons, équivalents de nos vernissages, il avait conçu sa «morale du bilboquet». Comme par hasard, j'ai réalisé il y a quelques années une bande vidéo représentant un bilboquet en action. Un jour, je filmerai mes rêveries d'un vidéaste solitaire.

Mots clef: J. J. Rousseau - peinture - vanité - vidéo.

Sammandrag: För en konstskole elev som jag, engagerad i ett bildskapande i början av 80-talet, så betydde videokonstens originella utopi ett nytt sätt att uttrycka sig konstnärligt. Sett på samma gång som en andning och en möjlighet att uppfrächa mitt arbete och slippa ut ur avant-gardets estetiska återvändsgränd som vi den här tiden satt fast i tvisten : neo-expressionistiskt måleri/ konceptuell-minimalistisk konst.

Det gällde alltså för mig att fortsätta måla, men med video. Därav två grundläggande frågor som oavbrutet föder mina tankar och mitt arbete. Kan man se videon i måleri ? Kan man se måleriet i video ? Originaliteten i mitt videokonstverk har alltid varit denna estetiska och historiska förankring i konsthistorien parallellt med en ingående studie i det elektroniska mediets kvaliteter i skenet av koncept som Vanitas och Video-Tavlor.

Jag refererar gärna till filosofen Jean-Jacques Rousseau. I de uttråkade salongerna, nutidens vernissage, hade han satt ihop sin "kendama-moral". Som av en slump gjorde jag för några år sedan ett videoband där man ser en kendama i funktion.

En dag kommer jag att filma mina fantiseringar om en solitär videokonstnär.

Nyckelord: J. J. Rousseau - måleri - vanitéer - video. 